\title{
Judicial Independence and Accountability in Cameroon: Balancing a Tenuous Relationship
}

\author{
Laura-Stella Eposi Enonchong* \\ Warwick School of Law, The University of Warwick, Coventry CV4 7AL, UK
}

\begin{abstract}
This article examines Cameroon's approach to judicial accountability focusing on its political accountability to the executive. The article contends that the judiciary in Cameroon is excessively accountable to the executive, a position which has resulted to the absence of judicial independence. It also contends that a constitutional reform is necessary to restructure the relationship between the executive and the judiciary and to reform the institutions of judicial insulation in order to provide adequate balance between independence and accountability.
\end{abstract}

\section{Keywords}

Cameroon, rule of law, executive interference, judicial independence, judicial accountability, political accountability, legal department

\section{Introduction}

Conventional wisdom holds that judicial independence and accountability are vital conditions for enhancing the judiciary's role in advancing the rule of law, good governance and effective human rights enforcement. There is nevertheless a potential tension between accountability and independence. That tension is particularly poignant in a system of accountability that relies heavily on the political branches. Excessive political accountability may undermine both the institutional independence of the judiciary and personal independence of judges by creating career oriented imperatives for acting in favour of the political branches. That is exacerbated in the absence of corresponding safeguards to pre-empt the arbitrary use of accountability mechanisms.

A classic example of such a tension exists in Cameroon where political accountability has adversely impacted on the individual independence of judges and the

\footnotetext{
* E-mail: L-S.E.T.Enonchong@warwick.ac.uk. The author is a PhD Candidate, Warwick School of Law. A version of this article was presented at the Fifth Annual Conference of the African Network of Constitutional Lawyers (ANCL) on 'Nurturing Judicial Independence and Accountability in African States' (Lagos, 17-19 May 2012). The author gratefully acknowledges the funding from the University of Warwick and the ANCL for participation in the conference. The author is also grateful to the delegates at the conference for their very stimulating engagement with the paper and for their very helpful comments. The usual disclaimers apply.
} 
institutional independence of the judiciary. Political accountability, as understood here, refers to the extent to which judges are accountable to other branches of government for such issues as tenure, terms and conditions of service and appropriation. ${ }^{1}$ It will be argued in this article that Cameroon's political accountability model places the judiciary in a subservient position to the executive, given that the judiciary relies entirely on the executive for appointment, promotion, discipline and remuneration through mechanisms which are neither transparent nor objective. The absence of transparency or objectivity has facilitated the arbitrary use of those features to inappropriately control the judiciary and to victimise individual judges who have failed to unduly protect the interest of the executive. Thus, while the Constitution recognises judicial independence, the judiciary is structured in a way that makes it wholly accountable to the executive to the point that independence is severely compromised. In the light of these observations, the article explores possible approaches to achieving a more appropriate balance between independence and accountability through constitutional reform.

By focusing on political accountability, the article does not intend to undermine other forms of accountability. However, it takes the view that in Cameroon, this dimension needs to be addressed in order to provide scope for other forms of accountability to flourish.

The article is divided into five main sections. After this introduction, Section 2 discusses the relationship between independence and accountability to demonstrate their complementarity and also highlight the potential tension in that relationship. In Section 3 the paper analyses Cameroon's model of political accountability. It will seek to show how excessive political accountability undermines judicial independence in Cameroon. Section 4 offers some proposals on how to recalibrate the relationship between independence and accountability in Cameroon. A summation of the discussion will be found in Section 5.

\section{The Interrelation between Judicial Independence and Accountability}

Judicial accountability has been described as a complementary concept to that of judicial independence and is seen as a justification for independence. ${ }^{2}$ According to Stephen Burbank, both concepts can be more appropriately described as 'different sides of the same coin' rather than being potentially conflicting. ${ }^{3}$ The complemen-

\footnotetext{
1) Wendell Griffen, 'Comment: Judicial Accountability and Discipline' (1998) 61(3) Law and Contemporary Problems 75-77.

2) Charles Geyh, 'Rescuing Judicial Accountability from the Realm of Political Rhetoric' (2006) 56(4) Case Western Law Review 911-936, at p. 916; Frances Zemans, 'The Accountable Judge: Guardian of Judicial Independence' (1999) 72 Southern California Law Review 625-655, at p. 631.

3) Stephen Burbank, 'The Architecture of Judicial Independence' (1999) 72 Southern California Law Review 315-351; Burbank, 'The Past and Present of Judicial Independence' (1996) 80(3) Judicature $117-122$, at p. 117-118.
} 
tarity of judicial accountability to the concept of independence can be understood by reference to the values that these concepts are purported to promote. ${ }^{4}$

Judicial independence, stripped of all technicalities, simply refers to the ability of a judge to render decisions based on the facts of the case and the law without undue interference or influence from the executive or legislative branches or the public. ${ }^{5}$ Independence is not an end in itself but possesses an instrumental value. ${ }^{6}$ It promotes a number of universally accepted values such as the impartiality of the judge, the rule of law and the separation of powers. ${ }^{7}$ Given the significant values that independence is meant to promote, certain conditions must necessarily exist to pre-empt potential external influence or interference with the adjudicatory process and to endow the judges with the necessary capacity to provide the requisite standard of justice. Those conditions, otherwise known as institutions of judicial insulation, ${ }^{8}$ include measures to secure the judicial tenure (which consist of transparent mechanisms for appointments, promotions and discipline), adequate remuneration of judges and arrangements for administrative and financial autonomy of the judiciary. The idealistic expectation is that properly conceived such measures can preserve the requisite level of autonomy of the judiciary to secure decisional as well as institutional independence. ${ }^{?}$

Nevertheless, judicial independence does not end there. Independence must be complemented by accountability as the absence of accountability can undermine the same values that independence seeks to promote. As a separate arm of the government rendering a public service, the judiciary must be subject to checks and balances, hence the need for accountability. Accountability like independence has instrumental value and is not an end in and of itself. ${ }^{10}$ It ensures that judges

\footnotetext{
4) Mauro Cappelletti, The Judicial Process in Comparative Perspective (Clarendon Press, Oxford, 1989), 69-71.

5) Burbank, 'The Architecture of Judicial Independence' 336; Zemans, 'The Accountable Judge' 627; Diana Woodhouse, 'Judicial Independence and Accountability in the UK' in Guy Canivet, Mads Andenas and Duncan Fairgrieve (eds.), Judicial Independence and Accountability (British Institute of International and Comparative Law, 2006) 23; Charles Fombad, 'A Preliminary Assessment of the Prospects for Judicial Independence in Post-1990 African Constitutions' (2007) Public Law 233-257, at p. 235.

6) Joseph Raz, 'The Rule of Law and its virtues' (1977) 93 Law Quarterly Review 195-211, at p. 198, Geyh, 'Rescuing Judicial Accountability' 915; Burbank, 'The Architecture of Judicial Independence' 342; Zemans, 'The Accountable Judge' 633; Cappelletti, The Judicial Process, 70; John Ferejohn and Larry Kramer, 'Independent Judge, Dependent Judiciary: Institutionalising Judicial Restraint' (2002) 77 New York University Law Review 962-1039, at p. 974.

7) Ibid.

8) Some authors prefer to use alternative expressions like, elements, features or mechanisms. According to Rios-Figueroa and Staton the alternative expressions actually refer to institutional features designed to insulate judges from undue influence and should preferably be referred to as institutions of judicial insulation. See J. Rios-Figueroa and J. Stanton, 'Unpacking the Rule of Law: A Review of Judicial Independence Measures' (Caltech-USC Centre for the Study of Law and Politics and University of Texas Law School Symposium, 26-27 March 2009) 13, available online at http://lawgip.usc.edu/centers/cslp/ documents/Rios-FigueroaandStaton2009.pdf (accessed 12 March 2011).

9) Ferejohn and Kramer, 'Independent Judge, Dependent Judiciary', at p. 967-968.

10) Geyh, 'Rescuing Judicial Accountability', at p. 916-917.
} 
actually exercise their powers to safeguard the impartiality and integrity of the judicial process, to uphold the rule of law and promote effective administration of the judicial system. Judicial accountability reduces the incidence of an errant judiciary that is not responsive to its public duty to administer justice in a fair, impartial and consistent manner. It is in this sense that Burbank regards independence and accountability as different sides of the same coin. In Brazil, for instance, the judiciary is independent but that has not been accompanied by appropriate accountability mechanisms. ${ }^{11}$ As a result, independence has been abused to the point that the judiciary has become irresponsive to the society. It has been asserted that the lack of judicial accountability in Brazil has fostered a culture of corruption, mismanagement and inexpedient and prejudiced adjudication. ${ }^{12}$

Despite their conceptualisation as complementary concepts promoting identical values, there is an inherent tension in the two concepts as there is no definite formula to delineate where independence ends and where accountability commences. Just as too much independence has the potential of creating an unaccountable judiciary, stretched beyond reasonable limits, accountability has the potential of encroaching on judicial independence. Thus, to ensure that both concepts actually represent two sides of the same coin, accountability should not entail undue subjugation to external parties. ${ }^{13}$ The potential of accountability encroaching on judicial independence is translated into concrete manifestations when the mechanisms designed to secure independence are conceived in ways that render the judiciary excessively accountable to the same institution that guarantees independence. A possible scenario obtains in terms of political accountability by virtue of which judges are accountable to the executive for such issues as tenure, terms and conditions of service. As Nuno Garoupa and Tom Ginsburg note, judges who are accountable to the same institution that appoints them and determines the subsequent path of their career cannot be reasonably relied upon for independent and impartial decision making. ${ }^{14}$ Independence can be further undermined in the absence of objective or transparent mechanisms by which judges can be held accountable. Although political accountability may involve some aspects of legal accountability (such as the provision of sanctions for conduct specifically outlined as being subject to disciplinary procedures) the political

\footnotetext{
11) Carlos Santiso, 'Economic Reform and Judicial Governance in Brazil: Balancing Independence with Accountability' in Siri Gloppen, Roberto Gargarella and Elin Skaar (eds.), Democratisation and the Judiciary: The Accountability Function of Courts in New Democracies (Frank Cass, London, 2004) 161-180.

12) Santiso, 'Economic Reform and Judicial Governance', at p. 163 and 170-173.

13) Burbank, 'Judicial Independence, Judicial Accountability and Inter-branch Relations' (2007) 95 The Georgetown Law Journal 909-928, at p. 913.

14) Nuno Garoupa and Tom Ginsburg, 'Guarding the Guardians: Judicial Councils and Judicial Independence' (2009) 57(1) American Journal of Comparative Law 103-134. See also Lovemore Madhuku, 'Constitutional Protection of the Independence of the Judiciary: A Survey of the Position in Southern Africa' (2002) 46(2) Journal of African Law 232-245, at p. 234.
} 
character of such systems undermines the transparency and objectivity that inheres in legal accountability measures. A political accountability mechanism that obscures legal accountability may potentially lead to a situation of repression or dependency of the judiciary. ${ }^{15}$

\section{Judicial Accountability and Independence in Cameroon}

This section puts the foregoing discussion on accountability and independence in context by examining the framework for independence and accountability in Cameroon. It aims to demonstrate the extent to which Cameroon's political accountability framework undermines judicial independence. The discussion is deployed in three subsections. The first subsection briefly discusses the structure of the judiciary. That discussion is considered relevant because the judiciary is characterised by a complex structure with features and thematic aspects which may be unfamiliar particularly to a non-civil law reader. ${ }^{16}$ The second subsection examines the framework of accountability and independence while the third discusses the imbalance inherent in that framework.

\subsection{An Overview of the Judicial Structure}

As is the position in France, the Cameroonian judiciary is a career judiciary made up of judges and prosecutors. ${ }^{17}$ They receive a common training in the National School of Administration and Magistracy (Magistracy Section) and therefore share a common status as judges. Upon completion of training and in the course of their career, judges can be appointed to serve either on the bench as adjudicators, in the Legal Department as prosecutors or in the Ministry of Justice. ${ }^{18}$

\footnotetext{
15) Cappelletti, The Judicial Process, at p. 105-110.

16) For historical reasons, the judicial structure in Cameroon is a French civil law oriented model. As such, it replicates some of the features of the French judiciary. Cameroon was formerly a United Nations trust territory administered separately by Great Britain and France. Although it has preserved both its British common law and French civil law heritage by operating a bijural legal system, the constitutional system is predominantly influenced by its French heritage.

17) The French language version of the Cameroonian Constitution refers to magistrat du siège to distinguish from prosecutors (article 37(2)). This is the categorisation applied in the judiciary in France and the explanation of that distinction according to the French Ministry of Justice is that while judges 'of the bench' preside over cases, prosecutors otherwise know as 'magistrats debout' (standing judges), who share the same status as judges 'stand' during judicial proceedings. See Ministère de la Justice (Republique Française), 'Les Magistrats', available online at http://www.ado.justice.gouv.fr/php/page.php?ref=3a (accessed 16 August 2012).

18) Decree No. $95 / 048$ of 8 March 1995 on the Status of the Magistracy, amended by Decree No. 2004/080 of 13 April 2004 (hereafter SOM), article 1. See also Carlson Anyangwe, The Magistracy and the Bar in Cameroon (CEPER, Yaounde, 1989), 41-42. There are also personnel such as clerks, registrars, notaries, bailiffs and judicial police officers, known as auxiliaries of justice who assist in the entire administrative system.
} 
In addition, there is a juge d'instruction (a judge of the bench) responsible for conducting preliminary investigations into alleged criminal offences. ${ }^{19}$

The Legal Department is a central feature of the judiciary in general and the prosecution in particular. There is one Legal Department attached to a Supreme Court, Appeal Court, High Court and Court of First Instance. ${ }^{20}$ This department is also considered a department in the Ministry of Justice and facilitates the overseeing of the judiciary by that Ministry. ${ }^{21}$ The department is headed by the Procureur Général in the Supreme and Appeal Courts (Directly responsible to the Minister of Justice ${ }^{22}$ and a State Counsel in the lower courts (directly responsible to the Procureur Général of the Court of Appeal within its geographical jurisdiction). ${ }^{23}$ The role of the department is to enforce laws, regulations and judgments and in criminal matters to investigate, issue warrants and prosecute. ${ }^{24}$ Judges begin their career as magistrates and subsequently rise to the position of judges. In this article, to maintain consistency they will be referred to as judges. In addition, the expression, 'judges of the bench' will be used here to distinguish from prosecutors and juge d'instruction who as explained earlier, share a common status as judges. This distinction is based on the categorisation provided in the laws governing the judiciary and is widely recognised and used in Cameroon. ${ }^{25}$

Against that background the framework for judicial accountability and independence in Cameroon is now examined.

\subsection{Independence and Accountability: The Framework}

In order to avoid repetition, this subsection applies an integrative approach to discuss the framework for judicial accountability and independence.

The independence of the judiciary is guaranteed by the Constitution which provides that the judicial power shall be independent of the legislative and executive power. ${ }^{26}$ It provides further that the President of the Republic shall be the guarantor of the independence of the judiciary. ${ }^{27}$ The President is responsible for appointments, promotions and disciplinary sanctions. ${ }^{28}$ In discharging those

\footnotetext{
19) Criminal Procedure Code (hereafter CPC), article 142(3) and Law No. 2006/015 of 29/12/2006 on the Organisation of the Judiciary (hereafter the Judicial Organisation Ordinance, JOO), ss. 14(1) (b) and 17(1) (b).

20) JOO, ss. 14(1)(c), 17(1)(c), 20(1)(b); Supreme Court Ordinance, s. 4(b) and CPC, s. 127.

21) Decree No. 2005/122 of 15 April 2005 Organising the Ministry of Justice (hereafter OMJ), articles 8 and $2(1)$, para 1.

22) JOO, s. 30(1).

23) JOO, s. 30(2).

24) JOO, s. 29(1)(2).

25) See, for instance, SOM; JOO; Anyangwe, The Magistracy and the Bar in Cameroon, 23-25; J. Muambo Evande; 'Empowering the Judiciary: Making Judicial Power Possible' (2001) 1 The Imperial Judge, SOWEMAC Judicial Journal 42.

26) Constitution of Cameroon, 1996, article 37(2).

27) Constitution of Cameroon, 1996, article 37(3).

28) Constitution of Cameroon, 1996, article 37(3).
} 
responsibilities, the President is to be assisted by the Higher Judicial Council (hereafter HJC) which is mandated to provide an opinion on all nominations to the bench and on disciplinary action against judicial and legal officers. ${ }^{29}$ It is not exactly clear if the inclusion of the HJC is a mechanism to diversify control of the judiciary in order to enhance the President's ability to guarantee judicial independence. The more probable position is that being modelled after the French judiciary under the Constitution of the Fifth Republic, it was an inevitable pattern for Cameroon to follow as the higher judicial council in France was vested with similar responsibilities. ${ }^{30}$ Nevertheless, the government of Cameroon in its Fourth Periodic Report to the United Nations Human Rights Committee described the $\mathrm{HJC}$ as part of the 'balancing mechanism'. ${ }^{31}$ While responding to allegations relating to the absence of judicial independence in Cameroon, the government asserted that the HJC is composed of distinguished personalities and characterised by broad representation and balance, which it argued, were unique characteristics that provide the necessary balance to pre-empt exclusive executive control of the judiciary. ${ }^{32}$ This view however remains open to doubt as will be demonstrated further below.

A further means of promoting judicial accountability and independence is by way of specific provisions on substantive independence. The Constitution provides that 'Magistrates of the bench shall, in the discharge of their duties, be governed only by the law and their conscience'. ${ }^{33}$ To buttress that point, decisions are required to be written, setting out the reason upon which they are based in fact and in law. ${ }^{34} \mathrm{~A}$ judgment rendered in breach of those principles is considered invalid. ${ }^{35}$ The requirement for a written and reasoned judgment acts as a safeguard against judicial arbitrariness. In addition it provides the basis on which judicial decisions can be challenged on appeal and also commented on by other members of the public like the media and academics.

Another measure which attempts to achieve accountability and independence is through the recognition (albeit indirect) of security of tenure. Once appointed, judges are integrated into the civil service and enjoy a fixed tenure until retirement. ${ }^{36}$ Their appointment process follows a similar pattern to that in France. It begins with a competitive examination after acquiring a master's degree

29) Constitution of Cameroon, 1996, article 37(3); Law No. 82/14 of 26/11/1982 Organising the Higher Judicial Council (hereafter HJC Law), article 10.

30) French Constitution 1958, article 64.

31) United Nations Human Rights Committee, 'Consideration of reports submitted by States parties under article 40 of the Covenant on Civil and Political Rights: Fourth Periodic Report of Cameroon' (19-20 July 2010), CCPR/C/CMR/Q/4/Add.1, p. 62, para 176.

32) UNHRC, 'Fourth Periodic Report of Cameroon', p. 62, para 177.

33) Constitution of Cameroon, 1996, article 37(2). See also SOM, article 5(1) as amended.

34) $\mathrm{JOO}$, s. 6(4) and s. 7.

35) JOO, s. 7.

36) Judges retire at various ages: 58 years for first- and second-grade judges, 60 for third-grade judges, and 65 for fourth-grade and judges 'hors hiérarchie'. See SOM, article 71(2) as amended. 
in law or maitrise en droit. ${ }^{37}$ Successful candidates are then admitted into the School of Administration and Magistracy (henceforth ENAM) in the Magistracy Section to study for a two year period..$^{38}$ They are trained as judges without any distinction as to trial judges, prosecutors or investigating judges. At the end of the qualifying period they are appointed by presidential decree to serve either as judges on the bench, prosecutors, juges d'instruction or even to the Ministry of Justice. ${ }^{39}$ Additionally, the eligibility criteria accommodates persons with adequate professional experience of a minimum of five years obtained in Cameroon in the field of law (for instance as lecturers, bailiffs, court registrars or notaries), economics or finance. ${ }^{40}$

However, commendable as they may appear, as discussed below those mechanisms operate within a framework which undermines the same guarantees that they purport to enhance.

\subsection{Accountability and Independence: The Imbalance}

The tension between independence and accountability in Cameroon will be examined from two dimensions: the individual and the institutional. Each will endeavour to demonstrate the subservience of the judiciary and individual judges to the executive, the political nature of the HJC and the resultant effects on independence.

\subsubsection{The Individual Dimension: Accountability and the Judicial Tenure}

Although the arrangements for judicial independence as seen earlier appear to recognise the need for security of tenure, an in-depth examination of those mechanisms reveals that they actually place the judges in a subservient position to the executive.

For instance with regard to career development, evaluation and recommendations for promotion is executive centered. Evaluation of senior judges ${ }^{41}$ of the Supreme Court, Courts of Appeal and those serving in the Ministry of Justice is performed by the Minister of Justice who subsequently recommends the judges for promotion on the advice of the Secretary General and directors at the Ministry of Justice. ${ }^{42}$ Evaluation and recommendation for other judges in the Supreme Court and Courts of Appeal is done by the presidents of the Supreme Court and Courts of Appeal respectively. ${ }^{43}$ For judges in the High Courts and Courts of First

\footnotetext{
SOM, article 11(1) and (2).

SOM, article 11(1)(b).

SOM, article 11(1)(a)(b) as amended. See also SOM, article 6(1).

SOM, art 11(3).

41) That category includes the procureur général of the Supreme Court and the Courts of Appeal and judges in the Ministry who have attained the level of directors or secretary general in the Ministry.

42) SOM, article 31(1)(a)-(f), (2)-(4).

43) SOM, articles 32(2), 34(1).
} 
Instance responsibility lies with the president of the Court of Appeal of that geographical jurisdiction, ${ }^{44}$ on the advice of the presidents of the respective courts. ${ }^{45}$ Individual judges not recommended may submit a personal request to the Minister through their hierarchical superior (procureur général or president of the court). ${ }^{46} \mathrm{~A}$ list comprising the names of judges recommended for promotion is submitted by the Minister to the $\mathrm{HJC}$ together with reports from the evaluation. ${ }^{47}$ The final list is drawn up by the $\mathrm{HJC}^{48}$ on the basis of the number of votes accorded individual judges by members of that institution. ${ }^{49}$ The recommendations are transmitted to the President of the Republic who makes the final decision on promotions and appointments by decree..$^{50}$

On the face of it, the process appears rigorous as it seems to involve a number of stages and different institutions/personalities. However, there are at least two important points worth noting. The first is that, the Minister and other executive authorities in the Ministry control the initial stages of the evaluation process (at least for the most senior judges). This is not entirely satisfactory as it is inconceivable to expect that executive authorities would be aware of the necessary details of the performance of judicial officers to be able to undertake an objective assessment.

Secondly, there is no distinct separation of responsibilities between the personalities charged with evaluation and nomination, and the institution responsible for recommendations and final appointment. The HJC is composed of the President of the Republic as chair, the Minister of Justice as deputy chair, three parliamentarians, an independent personality appointed by the President, the president of the Supreme Court and three senior judges. ${ }^{51}$ It can be seen that (with the exception of the parliamentarians and independent personality) the institutions which make recommendations to the president are pervaded by the same personalities responsible for evaluation and nomination. This is an objectionable situation as it makes the evaluation and recommendation process unfair and restrictive. Some judges have expressed dissatisfaction asserting that the system is neither transparent nor objective and inhibits their individual independence. ${ }^{52}$ The entire

\footnotetext{
44) SOM, art 34(1).

45) SOM, article 34(2).

46) SOM, articles 36 and 39.

47) SOM, article 40.

48) SOM, articles 30(1)-(3), 42(2), HJC Law, articles 12, 18(1) and 19(1).

49) SOM, article 42(3)(4).

50) SOM, article 6(1). See also SOM, article 29(3).

51) HJC Law (as amended), article 1(1)(2)(3).

52) Mathias Epuli SCJ, 'Opening Address' (Seminar on 'The Independence of Justice and the Fight Against Corruption in the Judicial System', Yaoundé, March 2006), available online at http://www .coursupreme.cm/index.php?csc=allocution10 (accessed 16 March 2011); Helen Fonachu JA, 'The Criminal Justice System in Cameroon: Problems Faced with regard to Corruption', (Tenth International Training Course on Criminal Justice Response to Corruption, Tokyo, December 2008) 150, available online at http://www.unafei.or.jp/english/pdf/PDF_rms_all/no76.pdf (accessed 16 March 2011); Evande J, 'Empowering the Judiciary' 47-48.
} 
system of career development for both upper and lower level judiciary is structured in such a way as to ensure the responsiveness of the judges directly or indirectly to the executive through the involvement of executive officials at crucial stages of the career development process.

Another aspect of the career development process includes transfers which may be functional or geographical and are made by Presidential decree. With respect to functional transfers as noted earlier, judges can be transferred at various points in their career to serve on the bench, in the legal department or the Ministry of Justice. ${ }^{53}$ This is based on the French concept of le magistrat polyvalent ${ }^{54}$ which relates to the view that a judge should be able to serve various judicial functions. ${ }^{55}$ There are no specific criteria for transfers ${ }^{56}$ although presumably it may be guided by the promotion process discussed above. However, it is asserted within the judicial circle that transfers from the bench to the legal department are used as disciplinary measures against judges who exercise decisional independence against the interest of the executive. ${ }^{57}$ The measure is also seen as providing the opportunity for activist judges to be subjected to the control of the Minister. ${ }^{58}$ Similarly, geographical transfers are shrouded with the same problem of the absence of specific or transparent criteria. Transfers to remote parts of the country are also said to be made as disciplinary sanctions on judges who assert their independence against the executive. ${ }^{59}$

With respect to the disciplinary procedure specifically outlined in the law, it should be noted that the process is permeated by executive influence. To begin with, conduct that constitutes the basis for disciplinary action includes lack of professionalism, lack of integrity, impropriety, failure to adhere to the law, breach

\footnotetext{
53) See above, n. 18, at 5.

54) The concept of le magistrat polyvalent is of French origin which in principle entails that a judge can exercise investigatory, prosecutorial and adjudicatory functions. This practice dates back to the ancien régime in France during which a single judge exercised all three functions, although post-revolutionary reforms saw the reorganisation of the French judicial system and the role of the judge. So, a single judge can no longer exercise all three functions concurrently but judges can be appointed to any of these positions during their career. In Cameroon, the law affirms this practice. See for instance the requirement that nominations for appointments and promotions of judges whether from the bench to the legal department or the legal department to the bench should be submitted to the HJC. SOM, article 6(2).

55) Anyangwe, The Magistracy and the Bar, 42.

56) Epuli SCJ; 'Opening Address'; Fonachu JA, 'The Criminal Justice System in Cameroon', 150; Evande J, 'Empowering the Judiciary' 47-48.

57) Charles Fombad, 'Cameroon's Emergency Powers: a recipe for (un)constitutional dictatorship?' (2004) 48 Journal of African Law 62-81, at p. 79; Nelson Enonchong, 'Human Rights Violations by the Executive: Complicity of the Judiciary in Cameroon' (2003) 47 Journal of African Law 265-274, at p. 270; Anyangwe, The Magistracy and the Bar, 42-43, esp. n. 59.

58) This point is explained further below.

59) Anyangwe, The Magistracy and the Bar, 43; Enonchong, 'Human Rights Violations', 270; Fombad, 'Cameroon's Emergency Powers', 79.
} 
of duty to the state ${ }^{60}$ and breach of the judicial oath. ${ }^{61}$ The formal disciplinary procedure is triggered by the Minister of Justice, who upon receipt of a potential disciplinary file, transfers such to the HJC. ${ }^{62}$ Upon receipt, the HJC informs the President of the Republic who appoints an ad hoc investigatory commission from among the members of the HJC. ${ }^{63}$ The report ensuing from the investigation is made available to the $\mathrm{HJC}$ and the judge in question. ${ }^{64}$ Based on the report, a disciplinary hearing is conducted by the $\mathrm{HJC}^{65}$ during which the judge under investigation must be present and may be represented by a colleague or counsel. After the hearing, the $\mathrm{HJC}$ undertakes further deliberations which are secret and held in the absence of the judge or his counsel. ${ }^{66}$ The recommendations are subsequently transmitted by the Minister to the President of the Republic ${ }^{67}$ who ultimately sanctions the judge by presidential decree. ${ }^{68}$ The sanctions range from elimination from the promotion list, a freeze on promotion for a maximum of two years, declassification, early retirement, temporary suspension for a maximum of two years and dismissal with or without pension. ${ }^{69}$ Less severe sanctions include a reprimand or a caution dispensed by presidential order on the advice of the $\mathrm{HJC}^{70}$

The disciplinary system has a number of features which have the potential of infringing on judicial independence. For instance, the conducts that are susceptible to disciplinary action are very broadly defined without some form of objective criteria to identify them. Further, although disciplinary sanctions and conducts have been outlined, the law is silent on the possible corresponding sanctions to be applied to particular misconduct. The assessment is left at the discretion of the HJC, the Minister and ultimately the President of the Republic. This creates scope for wide discretion and possible arbitrariness as a severe sanction may be imposed on a rather minor misconduct. Moreover, given that the decision on a disciplinary conduct cannot be appealed against, there is no scope for a judge to challenge the objectiveness of a disciplinary procedure, a sanction or the severity of it in relation to an alleged misconduct.

\footnotetext{
60) SOM, article 46. See SOM, article 23.

62) SOM, article 62 (1)(2).

63) SOM, article 50(1)(a), HJC Law, article 26(2).

64) SOM, article 57(3), HJC Law, article 29.

65) HJC Law, articles 30-32.

66) SOM, article 59(1)(2), HJC Law, article 33.

67) SOM, article 59(3).

68) SOM, article 60(1); HJC Law, article 34.

69) $\mathrm{SOM}$, art 47(1)(c)-(j).

70) SOM, 49(1).
}

61) The judicial oath is taken by judges upon their first appointment as members of the judiciary. They swear before God and man to render justice impartially, equally and with regard to the laws and customs of the Cameroonian people, without fear or favour and to conduct themselves with dignity and loyalty. 
Another weakness in the system can be gleaned from the actual role of the HJC in regulating the disciplinary procedure. Members of the institutions are charged with the initial process of investigation, preparing and submitting of reports, as well as the later stages of the hearing and formulating recommendations. There appears to be little scope for objectivity as the HJC can be considered 'prosecutor' and 'juge' in the same disciplinary matter from the perspective that it carries out the investigation (rather than an independent body) in addition to the hearing and the decision making. Although it may be argued that the investigatory commission is made up only of a few members, it is also the case that the investigation is undertaken on behalf of the entire institution and particularly commissioned by the President of the Republic. For the purpose of transparency and indeed objectivity, it would seem more appropriate that the investigation is carried out by personalities independent of the HJC.

Assuming that the $\mathrm{HJC}$ had scope for a measure of objectivity, in any case, the impact of its recommendations is limited. It is endowed with the nominal responsibility of providing its 'opinion' rather than a binding recommendation to the President. ${ }^{71}$ This is a particularly objectionable position given that the HJC sits as an institution which includes the President as chair, deliberates and arrives at recommendations as an institution. Yet, the Minister transmits the same recommendations to the President to unilaterally decide whether or not to proceed with the recommendations arrived at by the institution. The President can disregard the recommendations and rely on his personal opinion guided (or not) by the facts as presented in a particular case. In 2005 for instance, the HJC recommended disciplinary sanctions against thirteen judges for professional misconduct ranging from partiality, corruption and abuse of office. However, only two judges were eventually sanctioned by the President without any indication as to why the others were exculpated. ${ }^{72}$

An argument that the $\mathrm{HJC}$ is an objective institution ${ }^{73}$ is unconvincing particularly in the light of its composition which potentially obviates against its independence. ${ }^{74}$ In addition the President retains discretion to select the rest of the membership as they are appointed by presidential decree from amongst nominees originally designated by their peers. ${ }^{75}$ For instance, the three parliamentarians are appointed by the President from a list of twenty nominees voted by parliament, while the judges are appointed from a list of ten nominated by the Supreme Court. ${ }^{76}$ Thus, assuming that their initial nomination was objective and,

\footnotetext{
71) HJC Law, article 13(2).

72) See Decrees No. 2006/001 and No. 2006/002 of 03/01/2006 to Dismiss a Magistrate, published in Cameroon Tribune, Issue No. 8509/470 of 4 January 2006. The decrees are also available online at http:// www.spm.gov.cm/en/documentation/laws-and-statutory-instruments/news-browse/5.html.

73) As argued by the government. See above, n. 32, at 7.

74) See above, n. 51, at 9.

75) HJC Law, article 1(3)(a)-(c) (4) and article 2.

76) HJC Law, article 1(4).
} 
therefore, some measure of independence could be envisaged, the final appointment process dominated by the President undermines that possibility. Given the nature of its composition, it is doubtful that such an institution would be more inclined to protect the independence of the judiciary than to protect the interest of the President. A Supreme Court judge has in fact condemned the structure of the $\mathrm{HJC}$ and the absence of adequate judicial representation. ${ }^{77}$ In a recent communication before the African Commission, ${ }^{78}$ Cameroon was held in breach of Article 26 of the African Charter. ${ }^{79}$ The Commission emphatically expressed dissatisfaction with the composition of the HJC stating that within that framework it could not provide the necessary guarantee of judicial independence. ${ }^{80}$

The judicial tenure is structured in such a way as to ensure complete accountability to the executive and in particular to the President. There appears to be no distinct criteria on which the various aspects of the judicial career are based. ${ }^{81}$ Judges have repeatedly objected to that system asserting that it inhibits their individual independence. ${ }^{82}$ The absence of objectivity and transparency and the political nature of the HJC are fundamental aspects which provide scope for the executive to control the outcome of cases and the career of judges. As Epuli SCJ and Carlson Anyangwe have acknowledged, various aspects of the judicial tenure (appointment, promotions, transfer and discipline) are used as punitive measures against judges. ${ }^{83} \mathrm{~A}$ judge being aware of his precarious terms of office or being interested in advancing his judicial career is unlikely to completely fail to reflect the interest of the executive in his decisions. ${ }^{84}$ This is particularly so where the executive has a vested interest in a matter before the courts. The apprehension of executive backlash has been witnessed in some politically sensitive cases where some judges have applied creative interpretations of the law ostensibly to unduly protect the executive. Others who have erred on the side of the executive have been subjected to reprisals from the latter.

The case of The People v. Nya Henry ${ }^{85}$ is particularly illustrative. In that case, the respondents, mostly members of the Southern Cameroons National Council (SCNC), an opposition movement advocating political independence of Anglophone Cameroon from the Francophone section, were arrested on October 1, 2001

\footnotetext{
77) Epuli SCJ, 'Opening Address'.

78) Gumne et al. v Cameroon, Communication No. 266/2003 ACHPR (05/2009), Ex.CL/529(XV) Annex 4.

79) Article 26 of the African Charter on Human and Peoples' Rights provides that state parties shall have the duty to guarantee the independence of the judiciary and allow the establishment and improvement of appropriate national institutions entrusted with the rights and freedoms guaranteed by the Charter.

80) Gumne et al v Cameroon, 39-40.

81) Epuli SCJ, 'Opening Address'; Fonachu JA, 'The Criminal Justice System', 150; Evande J, 'Empowering the Judiciary', 47-48.

82) Ibid.

83) See above, n 57, at 10 .

84) Anyangwe, The Magistracy and the Bar, 33.

85) The People v Nya Henry (2005) 1CCLR, 61.
} 
during peaceful celebrations commemorating the end of British colonial rule in Southern Cameroons. They had applied for and were granted bail by the trial judge but that order was defied by the Legal Department as a result of which they were not released. In fact, the Procureur Général had instructed the Legal Department not to comply with the bail order. ${ }^{86}$ The trial judge was particularly saddened by the fact that 'the Procureur Général of the North West Province, the highest officer I know to be in charge of public prosecution, in this province' was prepared to undermine court orders. ${ }^{87}$ The Legal Department instead brought further charges against the respondents before the same judge who considered defiance of the bail order to be a breach of the respondents' right to the presumption of innocence. In consequence, he stayed the proceedings before the court and ordered their immediate release. ${ }^{88}$

The Legal Department appealed that decision before the Bamenda Court of Appeal. ${ }^{89}$ The Appeal Court held that the decision to grant bail was wrong as the respondents had not been charged prior to the decision to release them on bail and particularly because the prosecution had asked for more time to prepare a counter-affidavit. ${ }^{90}$ It was curious how the Appeal Court arrived at that position given that the law applicable at the time provided a 48 -hour limit for filing a counter-affidavit in urgent applications. ${ }^{91}$ The Legal Department had had over five days to prepare this counter affidavit and yet it needed more time to do so. The trial judge found that to be highly irregular as it would have meant that the respondents would continue to be in detention in breach of their right to personal liberty. Thus, the bail order was to prevent further breaches of that right and their right to the presumption of innocence. The Court of Appeal mindful of those facts was of the opinion that the case was 'serious', without outlining the circumstances that made it serious or exceptional to warrant more than the mandatory time to prepare a counter-affidavit. ${ }^{92}$ It did not address the issue of the violation of the respondents' fundamental rights. Rather, it seemed to align more with the Legal Department and was of the view that by staying the proceedings in the trial court, the judge deprived the Legal Department of the opportunity to present its evidence against the respondents. In arriving at that position, the Appeal Court relied neither on legislation nor any judicial authority to support that position. ${ }^{93}$

\footnotetext{
86) Nya Henry (2005), 64

87) Nya Henry (2005), 64.

88) Nya Henry (2005), 61

89) The People $v$ Nya Henry (2005) 1CCLR, 61, revd, BCA/MS/11C/2002 (unreported).

90) Enonchong, 'Human Rights Violations', 270-271.

91) Dr Martin Lumav The People (2002) ICCLR 6, 8. This application fell within that category given that some of the respondents were vulnerable people, with poor health and advanced in age.

92) Enonchong, 'Human Rights Violations', 271.

93) Enonchong, 'Human Rights Violations', 268.
} 
Meanwhile, the trial judge had based his decision on the applicable law ${ }^{94}$ and the well established principle in Connelly $v$ D.P.P. ${ }^{95}$ that the court had inherent powers to protect its process from abuse. ${ }^{96}$ As an appellate Court which should provide decisional accountability by way of reviewing the lower court's decision, its failure to refer to the law or judicial authority to challenge the decision of the lower tribunal is disappointing. It seemed rather more interested in protecting the interests of the executive regardless of serious breaches of fundamental rights. It even failed to condemn the Procureur Général's conduct (the instructions to disregard the bail order) as a breach of duty $^{97}$ and that it perpetrated fundamental rights violations. ${ }^{98}$ The Court of Appeal did not hesitate to reverse the trial court's decision.

Given the political nature of that case, it is not difficult to understand why the Legal Department and the judges in the Appeal Court went to extreme lengths to protect the executive. Their careers were at stake and in order to pre-empt possible negative repercussions they seemed compelled to engage in appalling judicial conduct. Their position can be understood more in the light of the outcome of the trial judges' career. The latter was aware of the potential repercussion from the executive as he called on the national and international community and 'those who cherish the status of this country as a state of law [to] keenly follow-up ... any developments in the career of this magistrate after this case'. ${ }^{99}$ It therefore came as no surprise when he was eventually transferred from the bench to the legal department in another jurisdiction. ${ }^{100}$

A similar outcome on the career of some judges was registered in Wakai $v$. The People, ${ }^{101}$ a case concerning a bail application made to the Mezam High Court. The applicants were supporters of the main political opposition party the Social Democratic Front (hereafter SDF). They arrested following demonstrations in protest of the results of the 1992 presidential elections, which were allegedly rigged in favour of Cameroon's incumbent President Paul Biya. The proclamation of the results sparked widespread demonstrations in Bamenda, the geographical base of the SDF. A State of Emergency was proclaimed in that area, leading to the arrest of a large number of people including the applicants. They had been arrested under very irregular circumstances. For instance, some were

\footnotetext{
94) The law applicable at the time was section 301(1) of the Criminal Procedure Ordinance which provided that a complaint dismissed on its merits shall result in the acquittal of the accused.

95) Connelly v D.P.P. [1964] AC 1254, 1354. See also Enonchong, 'Human Rights Violations', 267.

96) Enonchong, 'Human Rights Violations', 266-267. See also Andrew Choo, Abuse of Process and Judicial Stays of Criminal Proceedings (Oxford University Press, New York, NY, 2008) 5-10.

97) Pursuant to the Cameroonian Criminal Procedure Code (CPC), s. 545(2) the Legal Department has the primary responsibility to oversee the execution of bail orders and other court orders.

98) Enonchong, 'Human Rights Violations', 269.

99) Nya Henry (2005), 66.

100) Enonchong, 'Human Rights Violations', 270; Fombad, 'Cameroon's Emergency Powers', 79.

101) Wakai and 172 Others v. The People (1997) 1CCLR 127.
} 
arrested at night, others without warrants (although warrants were later issued by the respective administrative authorities and backdated to validate the arrests). Further, others were arrested pursuant to banditry laws which had no relevance to the state of emergency and yet others were arrested in different jurisdictions and brought to the Northwest to be made subject to the emergency law. The applicants were incarcerated in a detention centre notorious for torture and were held for longer than the four-month limit imposed by the emergency legislation. ${ }^{102}$ The Court, noting the irregularities, condemned the arbitrariness of the government and admitted the applicants to bail. However, the government failed to release the applicants and instead transferred them to Yaoundé, a different jurisdiction from the Court which ordered their release. ${ }^{103}$ With regards to the judges, their independence was sanctioned. The lead judge was transferred from his position as president of the High Court to the Legal Department, while the other two judges were dispersed to remote areas. ${ }^{104}$

Extensive executive control of the judicial tenure potentially impinges on judicial independence particularly in the context of the repressive nature of executive backlash against judges who dare to exercise decisional independence. The subordination of the judiciary and repressiveness of the political accountability system is further exhibited in the institutional relation between the executive and the judiciary.

\subsubsection{The Institutional Dimension: Inter-branch Relations and Accountability}

From an institutional perspective, accountability enhances the judiciary's ability to be responsive to the public, providing access to justice and efficient and expeditious administration of justice. ${ }^{105}$ Devices aimed at promoting institutional accountability and independence include the provision of adequate resources and internal procedures to regulate the administration of the courts. In Cameroon, the judiciary is accountable primarily to the executive at the institutional level, a situation which adversely affects the institutional independence of the judiciary. The situation emanates from the fact that the judiciary is perceived as a department in the Ministry of Justice. ${ }^{106}$ As such it is reliant on the executive for funding, hierarchically subordinated to the latter and liable to interference with the internal administration of the courts and judicial processes.

In terms of financial independence, the reliance of the judiciary on the Ministry of justice for its funding adds to the armory of accountability devices within the scope of the executive that can utilize it for its own ends to the detriment of

\footnotetext{
102) The Court described it as a place where 'God is unknown and satan reigns therein'. See Wakai, 141.

103) Fombad, 'Cameroon's Emergency Powers', 80.

104) Fombad, 'Cameroon's Emergency Powers', 80; Evande J, 'Empowering the Judiciary', 47.

105) Geyh, 'Rescuing Judicial Accountability', 918.

106) Decree No. 2005/122 of 15 April 2005 Organising the Ministry of Justice (hereafter OMJ), article 8.
} 
the institutional independence of the judiciary. ${ }^{107}$ Experience elsewhere has demonstrated that where the executive unilaterally controls the judiciary's budget, that power has been used to maliciously restrict financial allocations to it. ${ }^{108}$ Moreover, the remuneration and allowances of judges are determined by the executive through decrees that are susceptible to change at any time. ${ }^{109}$ That arrangement does not provide financial security as would be the case were judicial budgets, salaries and allowances were charged to a consolidated fund which cannot be reduced at the will of the executive. Judges in Cameroon perceive the current arrangement as objectionable and assert that it may be used to exert undue influence on the judiciary. ${ }^{110}$ Such a scenario was witnessed in 1997 prior to legislative elections in which the judiciary played a significant role in vote counting commissions. ${ }^{111}$ The financial status of the judiciary was unexpectedly improved through an increase in administrative budgets and the salaries and allowances of some senior judges a number of whom were prospective heads of vote counting commissions. ${ }^{112}$ Although augmentation is important to promote personal independence and effective judicial administration, the 1997 salary increases came at a very auspicious time for the government, which rendered the motive of the executive questionable.

Judicial accountability to the executive as a department in the Ministry of Justice also implies that the judiciary is susceptible to similar administrative supervisory processes accorded other departments. ${ }^{113}$ Accordingly, the Ministry supervises court processes, ${ }^{114}$ schedules dates and times for court sessions (with the exception of the Supreme Court) pursuant to non-binding recommendations from the presidents of the various courts, ${ }^{115}$ organises and oversees training of judicial personnel. ${ }^{116}$ Accountability to the executive is also demonstrated through the provision mandating the first president of the Supreme Court and procureur général to submit annual reports to the President of the Republic on the activities of the

\footnotetext{
107) Maurice Kamto, 'Les Mutations de la Justice Camerounaise à la Lumière des Développements Constitutionnels de 1996', (2000) 1, Revue Africaine des Sciences Juridiques 9-20, at p. 15-16; Anyangwe, The Magistracy and the Bar, 44.

108) Fombad discusses the examples of Malawi and Swaziland where the executive has been able to use such powers to exert pressure on the judiciary. See Fombad, 'A Preliminary Assessment', 245.

109) SOM, article 10(3). See also Evande J, 'Empowering the Judiciary', 48.

110) Evande J, 'Empowering the Judiciary', 48.

111) Fombad, 'A Preliminary Assessment' 255.

112) Decree No. 97/015 and Decree No. 97/016 of 22/01/1997 on Remuneration and Financial Benefits to the President and Procureur Général of the Supreme Court; and certain magistrates respectively. See also Fombad, 'A Preliminary Assessment' 255; Evaristus Fonkah, 'The Judiciary- not really credible' African News Bulletin, Issue No. 337 (Cameroon, 1 January 1998), available online at http://ospiti.peaceunit .it/anb-bia/nr337/eos.html (accessed 16 March 2011).

113) $\mathrm{OMJ}$, article 8.

114) $\mathrm{OMJ}$, article 11(1).

115) JOO, s.12(2)(a). The arrangements for the Supreme Court are that sessions are fixed by the first president of the Supreme Court in consultation with Parliament. See Supreme Court Ordinance, s. 23.

116) OMJ, article 60(1); SOM, article 17(1)-(4).
} 
Supreme Court. ${ }^{17}$ It may be argued that such executive controls are necessary to ensure the effective and efficient administration of justice, a public duty for which the government is responsible. As Shimon Shetreet argues, executive supervision of administrative aspects of the courts is a facet of the checks and balances system and does not inherently undermine independence as it is the duty of the executive to maximise the effectiveness of public services in the country. ${ }^{118}$ However, that supervisory role is only an acceptable facet of the checks and balances system to the extent that it does not impede on the independence of the judiciary. ${ }^{119}$ In the Cameroonian case, administrative interference, like financial dependence further subjects the judiciary to the unfettered control of the executive.

Further, tension between accountability and independence can be perceived in the context of the hierarchical relation between the judiciary and the Ministry of Justice. As a department in that Ministry, the judiciary is hierarchically linked to the executive through the Legal Department and supervised by the former. ${ }^{120}$ The law provides that, 'Members of the Legal Department and Legal Assistants shall be subordinate to the Ministry of Justice'. ${ }^{121}$ Thus, judges in the legal department, who act as prosecutors, are answerable to the Minister of Justice, through the hierarchy of the procureur général. ${ }^{122}$ Unlike judges of the bench who are required to render justice according to the law and their conscience, those in the Legal Department are required to act in accordance with the dictates of the Minister of Justice, as would be required of an ordinary public servant. ${ }^{123}$ That point was emphatically stated by the government of Cameroon in its Fourth Periodic Report to the U.N. Human Rights Committee. The government reiterated that 'given that Legal Officers represent the Executive in the Judiciary, they are bound to respect the principle of subordination to hierarchy'. ${ }^{124}$

It may be argued that given that the legal department is made up of prosecutors, they are not judges per se and may appropriately be treated as representative of the executive. In that case, their subordination to the executive is not inconsistent with judicial independence. Yet, that subordinate position may conflict with prosecutorial independence, which is a separate issue. What is of interest here is the fact that judges of the bench can be transferred to the legal department (and vice versa) at any point in their career. While in the legal department, prosecutors become accustomed to acting on the directives of the Minister and may not

\footnotetext{
117) Supreme Court Ordinance, s. 34.

118) Shetreet, 'Judicial Independence', 650-651.

119) Shetreet, 'Judicial Independence', 650-651.

120) $\mathrm{CPC}$, ss 60, 128 and 133(2). See also OMJ, articles 8 and 32(1), para 1.

121) SOM, article 3(1).

122) JOO, s. 30.

123) SOM, article 3(2).

124) UNHRC 'Fourth Periodic Report of Cameroon', p. 104, para. 384. A distinction is made between judicial and legal officers by the State of Cameroon in that report- while 'judicial officers' refers to judges of the bench, 'legal officers' refers to prosecutors in the legal department.
} 
pursue independent initiatives without prior authorisation from the latter. If subsequently transferred to the bench, a former prosecutor, now judge, is expected to exercise independence after having been trained to revere executive hierarchy. ${ }^{125}$ Anyangwe asserts that, a judge in that position cannot 'suddenly become independent and fearless', and is more likely to act as a prosecutor than an impartial judge. ${ }^{126}$ Similarly, the transfer of an activist judge from the bench to the legal department under the circumstances of control and supervision of the procureur général and ultimately the Minister provides opportunity for the judge to be 'cowed' into passivity. Moreover, being away from the bench implies that the judge is kept at a distance from adjudication thereby pre-empting any activism on his part. That perception of the 'repressive effect' of the legal department on prosecutors explains why transfers to it are considered as punitive measures against judges of the bench who exercise decisional independence against the executive. ${ }^{127}$

By and large, as demonstrated above, the political accountability of the judiciary to the executive dangerously encroaches on both the institutional independence of the judiciary and the independence of individual judges. In fact, as the English judge, Lord Phillips of Worth Matravers stated, individual independence is inseparable from institutional independence as the latter contributes enormously to the former. ${ }^{128}$ If the absence of independence is felt at the institutional level, it is unlikely that individual judges would be in a position to exercise their independence.

Moreover, in Cameroon the resulting impact from the tension between independence and accountability has also been felt at the level of the public from the perspective that there is no accountability to the public for judicial decisions or the effective and expeditious administration of justice. The government of Cameroon reiterated in its Fourth Periodic Report to the Human Rights Committee that the 'court is not accountable to the public as far as their decisions are concerned'. ${ }^{129}$ The Cameroonian position is untenable particularly in the context of recent public denunciation of the judiciary as a moribund institution. ${ }^{130}$

\footnotetext{
125) Cf., Jacqueline Hodgson, French Criminal Justice: A Comparative Account of the Investigation and Prosecution of Crime in France (Hart, Oxford, 2005) 69-70, 224. Hodgson discusses the position in France where judges actually question their status whether they are investigators, prosecutors or adjudicators. In n. 25, at p. 70, Hodgson refers to Samet (2000:33) in which the role of the juge d'instruction is considered surprising and misleading and is being questioned whether he is a 'judge or investigator, defender of rights or pursuer of wrongs'.

126) Anyangwe, The Magistracy and the Bar, 43.

127) See above, n. 57 at p. 10.

128) Lord Phillips, 'Judicial Independence and Accountability: A View from the Supreme Court' (UCL Constitution Unit, launch of research project on The Politics of Judicial Independence, London, 8 February 2011), available online at http://www.supremecourt.gov.uk/docs/speech_110208.pdf (accessed 30 March 2011). Lord Philips was the first president of the UK Supreme Court.

129) UNHRC 'Fourth Periodic Report of Cameroon', p. 103, para. 380.

130) Dipanda Mouelle P; 'Allocution de Monsieur Le Prémier President de La Cour Suprême a L'occasion de La Rentrée Solennelle de Ladite Cour' (Yaoundé, 28 February 2008), available online at http://www
} 
Generally, the judiciary is widely acknowledged as an indispensable fabric in the stability of a state, its economic, social and political development, the protection of human rights and safeguarding the rule of law. In dispensing its public duties the judiciary should be accountable, yet to be effective, it should be independent. From the foregoing examination of Cameroon, it is evident that there is need to strike an appropriate balance between political accountability and independence. Such a position was inferred by Mouelle $\mathrm{P}$, the first president of the Supreme Court of Cameroon, when he asserted that accountability is not simply achieved by establishing rules to that effect without consideration of the risk of infringing on judicial independence. Although he failed to specifically outline some of the areas where independence and accountability were in tension, he was clear that there was need for reform. ${ }^{131}$

\section{Rethinking the Status Quo: Balancing Independence and Accountability}

Obtaining synergy between accountability and independence is by no means an easy project anywhere, ${ }^{132}$ not least in Cameroon. Many jurisdictions adopt specific mechanisms based on their peculiar circumstances and the purposes that the mechanisms are aimed to achieve. According to Mauro Cappelletti, a constructive model is a 'responsive model'133 which takes into account the need for independence and the equally important need for a responsible judiciary by developing a well thought out and balanced process involving the judiciary, the executive, the legislature and the civil society. Such a system of checks and balances promotes transparency and genuine accountability as the participation of diverse institutions inhibits subordination of the judges to any particular institution. ${ }^{134}$ In addition, it precludes the development of 'uncontrolled, irresponsible anarchy' of the judiciary by subjecting it to genuine and transparent accountability measures. ${ }^{135}$

With regards to Cameroon, developing a responsive model should commence with a re-conceptualisation of the constitutional status of the judiciary vis-a-vis the executive. Accordingly, the judiciary should be separate and independent from the executive. To that effect, the hierarchical link between the legal department, the procureur général and the Ministry of Justice should be ruptured. That

\footnotetext{
.coursupreme.cm/index.php?csc=allocution8 (last accessed 16 August 2012); Fombad, 'The Dynamics of Record-breaking Endemic Corruption and Political Opportunism in Cameroon', in Mbaku and Takougang (eds.), The Leadership Challenge in Africa: Cameroon under Paul Biya (Africa World Press, Trenton, NJ, 2004) 365, 389-390.

131) Mouelle P, 'Allocution du Premier President'.

132) Geyh, 'Rescuing Judicial Accountability', 914; Owen Fiss, 'The Right Degree of Independence', in Irwin Stotzky (ed.), Transition to Democracy in Latin America: The Role of the Judiciary (Westview Press, Boulder, CO, 1993) 55-72.

133) Cappelletti, The Judicial Process, 112-113; Shetreet, 'Judicial Independence', 655.

134) Cappelletti, The Judicial Process, 112-113; Garoupa and Ginsburg, Guarding the Guardians', 131.

135) Cappelletti, The Judicial Process, 112.
} 
link as seen above is a key feature in the accountability mechanism by which judges are made subject to the principle of subordination to hierarchy. The executive can perform its supervisory role on the judiciary without necessarily subordinating the legal department or the entire judiciary to the control of the Ministry of Justice. Maurice Kamto has argued conversely that that pattern of subordination acts as a form of accountability ensuring the consistent and impartial application of the law. ${ }^{136}$ Although he is keen to highlight the excessive executive dominance of the judiciary, he nevertheless argues that the link between the legal department and Ministry of Justice needs to be preserved to enable the government to exercise its duty of maintaining law and order and to prevent a system of 'government of judges' which can be disruptive to public order. ${ }^{137}$ Ironically, Kamto makes allusion to the Lewinsky-Clinton saga in the United States arguing that Clinton's prosecution was facilitated by a situation of 'government of judges' by which an absolutely independent judiciary and prosecution service motivated by individual political preferences and vindictiveness, used their authority to prosecute the President. ${ }^{138} \mathrm{He}$ fails to acknowledge however that the Lewinsky-Clinton saga demonstrated the sophisticated level of the checks and balances system in the United States through which even the highest executive official can be made subject to the rule of law.

With respect to Cameroon, Kamto's views on the hierarchical link obscure a fundamental feature of an appropriate checks and balances system which requires a separation of adjudicatory and prosecutorial functions as well as their personnel. The ability for judges to perform both functions interchangeably, conflicts with their independence. International standards recognise the potential detrimental effects of the characteristic duplication of judicial functions in some civil law systems. ${ }^{139}$ The Council of Europe, for instance, has stated that regardless of the fact that judges and prosecutors are part of the same legal system and may sometimes have similar functions, public prosecutors should not be judges. ${ }^{140}$ If Kamto's views were to be adhered to, it would require at a minimum that prosecutors and judges once initially appointed to the legal department and the bench respectively, should not subsequently in their career be transferred to either section. It is important that any career progression should be within their respective

\footnotetext{
136) Kamto, 'Les Mutations de la Justice', 17-18. For a perspective on the French approach, see Hodgson, French Criminal Justice, 80.

137) Kamto, 'Les Mutations de la Justice', 17-18.

138) Kamto, 'Les Mutations de la Justice', 18.

139) See for instance Principle F(f) of the African Principles and Guidelines on the Right to a Fair Trial and Legal Assistance in Africa, (Maputu, July 2003) and Guideline 10 of the UN Guidelines on the Role of Prosecutors (GA Res 43/173, 9 December 1988). See also Council of Europe Committee of Ministers Recommendation (2000) 19, The Role of Public Prosecution in The Criminal Justice System, 6 October 2000. Commentary on para. 17.

140) The Council of Europe Commentary to Recommendation (2000) 19, para. 21.
} 
services to maintain the distinct nature of their public duties and the institutions to which they are accountable.

Further, balancing accountability and independence also entails a re-conceptualisation of the constitutional notion of judicial independence. A constitutional provision stating that the judiciary shall be independent merely indicates a commitment but does not suffice. According to the first president of the Supreme Court, the commitment can be strengthened by unambiguous constitutional guarantees of judicial independence and devising rigorous, objective and transparent mechanisms for promotion, discipline and guaranteeing financial security. ${ }^{141}$ The reforms should include an independent process of assessment of judges for promotions and discipline which does not include the Minister. Moreover, the HJC should not be involved at every stage of the procedures. Rather, it can retain overall control and in that respect appoint independent committees to oversee the various stages involved in the procedures. Such a system presumably prevents the absolute reliance of the judiciary on the executive, thereby pre-empting excessive political accountability to the executive.

In South Africa, for example, the President appoints the Chief Justice and its deputy after consultation with the Judicial Service Commission (JSC) and leaders of parties represented in the National Assembly. ${ }^{142}$ The president and deputy president of the Supreme Court of Appeal are appointed after consultation with the JSC, ${ }^{143}$ while other judges are appointed on the advice of the JSC. ${ }^{144}$ In terms of disciplinary procedures, the Seychellois system is instructive. The process is regulated by the Constitutional Appointment Committee (hereafter the CAA) which is composed of three members, one appointed by the President of the Republic and the second, by the leader of the opposition. ${ }^{145}$ The two appointees are responsible for appointing the third member who is the chairman of that institution. ${ }^{146}$ When presented with allegations of misconduct of judges, the CAA appoints an independent tribunal to investigate the allegations and it supervises the activities of that tribunal. ${ }^{147}$ The tribunal which may consist of retired or serving judges and legal practitioners reports its findings and recommendations to the CAA. In consideration of the findings of the tribunal, the CAA recommends the appropriate disciplinary measures to the President who must act in

\footnotetext{
141) Mouelle P, 'Allocution du Premier President'. See also Fonachu JA; 'The Criminal Justice System', 150; Fombad, 'A Preliminary Assessment', 250. See further the African Commission's Recommendations on the Respect and Strengthening of the Independence of the Judiciary, 1996 (hereafter ACR), 4(h), (i), (m), (o) and (p) and U.N. Basic Principles on the Independence of the Judiciary, 1985 (hereafter UNBP), 10,13 and 18 .

142) Constitution of South Africa, s. 174(3).

143) Constitution of South Africa, s. 174(3).

144) Constitution of South Africa, s. 174(6).

145) Constitution of Seychelles, 1993, article 140(1)(a).

146) Constitution of Seychelles, article 140(1)(b).

147) Constitution of Seychelles, article 134(2)(a)(b).
} 
accordance with the recommendations. ${ }^{148}$ By involving independent institutions and a transparent and rigorous process, accountability can be enhanced without subjecting the judiciary to undue political control from the executive.

Again, in Cameroon in terms of financial arrangements that can secure independence and also ensure that the judiciary is accountable for its effective administration, Kamto has argued for the creation of an autonomous institution with jurisdiction to control the judiciary's budget. ${ }^{149}$ Another approach suggested by Anyangwe is for the judiciary's budget to be controlled by the Chief Justice through the registrar, a practice that existed in the former West Cameroon. ${ }^{150}$ What can be extrapolated from the two propositions are the creation of an independent institution and the involvement of the judiciary in determining and controlling its budget. It is suggested here that the HJC can be vested with that duty with the important caveat that the HJC itself be subject to reforms. Additionally, the judiciary's budget can be charged to a consolidated fund as is the case in Uganda, ${ }^{151}$ Botswana ${ }^{152}$ and a significant number of Commonwealth African countries. ${ }^{153}$ In that way, it is secured and less likely to be manipulated by one individual or institution to the disadvantage of the judiciary.

In Cameroon, while the constitutional provision regarding presidential responsibility to guarantee judicial independence should not immediately raise warning signals, it is axiomatic that the responsibility be exercised in conjunction with an independent and effective institution to pre-empt its arbitrary exercise. A key to that shared responsibility is the strengthening of the HJC. Generally, judicial councils (or judicial commissions in common law jurisdictions) are institutions designed to enhance independence and accountability and to develop an appropriate balance between the two concepts. ${ }^{154}$ Their ability to attain those objectives depends significantly on the institutional design (composition and competence). ${ }^{155}$ In Cameroon, the inadequate conceptualisation of those two aspects (composition and competence) contributes to the subordination of the judiciary to the executive.

With regard to composition it is recommended that membership be more diversified to include representatives from the civil society, lawyers, professors, all appointed by their peers through transparent mechanisms. ${ }^{156}$ An increase in

\footnotetext{
148) Constitution of Seychelles, article 134(3).

149) Kamto, 'Les Mutations de la Justice', 15-16.

150) Anyangwe, The Magistracy and the Bar, 44. See also Evande J, 'Empowering the Judiciary', 50.

151) Constitution of Uganda, s. 128(5).

152) Constitution of Botswana, s. 117.

153) Madhuku, 'Constitutional Protection of the Judiciary', 244.

154) Garoupa and Ginsburg, 'Guarding the Guardians', 204; Garoupa and Ginsburg, 'The Comparative Law and Economics of Judicial Councils' (2008) 27(1) Berkeley Journal of International Law 53-83, at p. 54.

155) Garoupa and Ginsburg, 'Guarding the Guardians', 204.

156) See for instance the judicial service commissions in South Africa (Constitution of South Africa, s.178(1)(a)-(k) and Ghana (Constitution of Ghana, s. 153)).
} 
judicial membership is also important to ensure that the judiciary is adequately represented to protect its interest. ${ }^{157}$ That is not to suggest that the judiciary should be in the majority. It is important to have a balanced representation in order to ensure that while the judiciary is adequately represented to pre-empt possible encroachment on its independence, the other members can hold the judiciary accountable. Again with regard to judicial membership, it should not be limited to senior judges so as to provide broad representation of the judiciary.

Moreover, it is necessary that the President and the Minister of Justice cease to be members of that institution in order to enhance its independence. In the Gumne case, the African Commission went further to recommend amendment of the HJC's composition to exclude executive members such as the President and Minister of Justice. ${ }^{158}$ The presence of these two officials seriously obstructs the ability of the HJC to function independently as the majority of its members are dependent (directly or indirectly) on the executive. ${ }^{159}$ In France, recent constitutional amendments to reinforce judicial independence have led to changes in the composition of the Conseil Supérieur de la Magistrature (CMS) excluding the President and Minister of Justice. ${ }^{160}$ The First President of the Cour de Cassation described the reform as intended to reinforce the independence of the judiciary which had appeared to be compromised by the presence of the President and the Minister of Justice in the CSM. ${ }^{161}$

Another reform of the $\mathrm{HJC}$ in Cameroon that has potential to contribute to judicial independence and accountability is reinforcing its authority. ${ }^{162}$ At present, the fact that it does no more than provide an opinion on appointments and

157) Cf., John Hatchard, Muna Ndulo and Peter Slinn, Comparative Constitutionalism and Good Governance in the Commonwealth: An Eastern and Southern African Perspective (Cambridge University Press, Cambridge, 2004), 151-154.

158) Gumne et al., 41.

159) Akiwumi has argued that the reliance of executive officials on Presidential appointments may turn such commissions into 'creatures of the... Presidents'. See M. Akilano and J. Akiwumi, 'The Independence of the Judiciary in Africa' (African Development Forum Conference on Independence and Accountability in Africa, Addis Ababa, 11-15 October 2004), available online at http://www.uneca.org/ adfiv/documents/speeches_and_presentations/speech_akiwumi.htm (accessed 12 February 2011). See also Madhuku, 'Constitutional Protection of the Judiciary', 238.

160) French Constitution, article 65(as amended). See also La loi organique du 22 juillet 2010 which gives effect to French constitutional reforms introduced in 2008. However, the Minister of Justice may have an observer status in any sessions of the CSM except sessions involving disciplinary hearings. Although the majority of CSM in Francophone Africa have maintained the traditional composition of that institution, there seems to be support for reforms excluding the President and Minister of Justice. Article 152(2) of the DRC Constitution of 2006 has altered the composition of the Congolese CSM to exclude the President and Minister of Justice.

161) Vincent Lamanda, 'Discours de M. Vincent Lamanda, Premier Président de la Cour de cassassion' (Audience Solennelle de la Cour de cassation, Paris, 7 January 2011), available online at http://www .conseil-superieurdelamagistrature.fr (accessed 11 March 2011).

162) Garoupa and Ginsburg assert that councils with extensive competencies turn to be stronger than those reduced to housekeeping functions. See Garoupa and Ginsburg, 'Guarding the Guardians', 121. 
discipline implies that it has no clout. ${ }^{163}$ It is therefore of nominal importance in terms of promoting the independence of judges while attempting to make them accountable. The proposition is for the HJC to play a more decisive role by making binding recommendations. This is important as it shifts the determination of the judicial tenure away from the discretion of the President. A similar position obtains in Seychelles where the President is responsible for making disciplinary sanctions against judges, but this is done pursuant to the binding recommendations of the CAA. ${ }^{164}$ Nigeria also operates a parallel system where the Constitution makes it incumbent on the President to appoint judges on the recommendation of the National Judicial Council, and with confirmation by the Senate. ${ }^{165}$

The above measures can be given further significance through their entrenchment. Presumably, their entrenchment as constitutional values makes them less susceptible to executive manipulations than is the current position under which fundamental aspects relating to independence and accountability are regulated by decrees and ordinary legislation.

\section{Conclusion}

Accountability and independence are both important predicates to a well functioning judiciary. Nevertheless, as demonstrated above, accountability stretched too far can significantly impair independence. This article has endeavoured to show that the political nature of the accountability mechanisms in Cameroon and their lack of transparency and objectivity have undermined judicial independence. It is therefore necessary or desirable for the judiciary to be extricated from that excessive executive control. A feasible recalibration of the relationship between independence and accountability in Cameroon would entail a constitutional overhaul of the relationship between the executive and the judiciary and the institutions of judicial insulation. This paper has endeavoured to offer some preliminary insights into possible directions that can be followed to achieve that objective.

\footnotetext{
163) In a press release relating to a meeting of the HJC in 2010, it was reported that with regards to the discipline of two judges, members of the HJC expressed their views during the disciplinary hearing but had to await 'the final decision by the President of the Republic in his capacity as President of the Supreme Council of Magistracy'. See Presidency of the Republic of Cameroon Palace Magazine, 'Supreme Council of the Magistracy Meets at Unity Palace' (Yaoundé, 8 July 2010), available online at http://www .prc.cm/index_en.php?link=le_mag/lecture_mag_enandid=399andlang=enandpos=2 (accessed $12 \mathrm{March}$ 2012).

164) Constitution of Seychelles, article 134(2).

165) Nigerian Federal Constitution, 1999, articles 231(2), 238, 250, 260, 266 and 271.
} 